\title{
Strategic alliance as a catalyst for restructuring of the global economy: a theoretical perspective.
}

\author{
Eke Donatus Izuogu \\ School of Business Education \\ Federal College of Education in Affiliation with Nnamdi Azikiwe University \\ Anambra State, Nigeria
}

\section{Key words}

Alliance, catalyst, global knowledge, restructuring, strategy, economic planning.

\begin{abstract}
This paper examines strategic alliance as a model for re-aligning the global economy towards sustainable peace and development in the emerging new world order. The paper aims at critically examining the existing positions/status of various countries of the world, particularly, the dichotomy between under-developed, developing and developed nations as well as regional integrations and separatists associations or groupings vis-à-vis the general economic positions of the various nations of the world, thus juxtaposing the highlights towards repositioning or restructuring of the global economy. The paper adopted a theoretical perspective with a view to unveiling the critical indices within the variables of interest and proposed a new direction in the academic genre of world economic conferences. The paper concludes that the world economy is evolving, and emerging trends indicate a tumultuous transition that requires global attention, rather than separatists' approach by individual nations or groups. The paper therefore, recommends, (i) immediate convocation of international/global conferences on economic restructuring cutting across all nations, irrespective of the status in economic growth; (ii) a re-alignment and adjustments in the barriers posed by nations on inter-regional employments; (iii) an increased tempo in cross-border exchange in various relationships in entrepreneurship studies as well as other key educational and skill development programmes, (iv) cross-fertilization of ideas, skills, competences and knowledge across nations irrespective of creed, color or location; (v) a total re-skilling, re-tooling and reinvigoration of mutual co-existence rather than rugged individualistic and self-reliance approach of nations. The paper is significant in policy analysis and global economic planning.
\end{abstract}

Introduction

The world economy in recent times is facing challenges; so much so that even the best economic pundits have failed in their various postulations leaving the uninformed in utter chagrin as to believe that the world is coming to an end! The present situation cut across dwindling economic fortunes of nations, global security threats, global warming, deforestation problems as well as radical social dismemberment of citizens across various nations. These challenges pose serious economic, social, and psychological threats to leaders of the various countries of the world. The rising unemployment statistics accentuated by the increasing literacy rates of nations and development in information and technology (ICT) have not helped matters.

Worried by these situations, world leaders have engaged in various strategic conferences covering large spectrum of thematic areas. In all these conferences, seminars, symposiums, and interactive meetings between leaders there still appear to be mutual suspicion among each other.

In Africa, for example, Nigeria/ South Africa relationship which is supposedly expected to be rosy and convivial beyond racial, ethnic, color and regional differences considering Nigeria's investment in South Africa during the apartheid regime, her citizens suddenly woke up to face all manner of hate and dastardly attacks on their personal businesses and attempt on their personal lives by certain groups of persons. The next thing was to tag it a name 'Xenophobic'. Much as these actions do not truly portray Nigeria/ South Africa relations, there are also various assaults and deprivations suffered by other citizens across the globe in several proportions without serious attention and support.

Sometimes, it seems as if the world leaders just sit and watch these molestations, maimings, killings and dehumanizing of citizens of another country without outright condemnations, sanctions, or 
possible repudiations. Although, there could be subtle reactions and undercurrents by these leaders, their actions are seen by the victims as not being prompt and enough to assuage their feelings and expectations. But the fact remains that an injury to one is injury to another. That is the spirit of comradeship! What is more obvious in the emerging world order is that no single nation can sit down and say to other countries "go to hell", in assumption of complete self-reliance, independence and self-sustaining without an iota of need from one another! When world leaders rise up in unison to condemn bad leaderships, mistreatment of one country's citizens by another country, recommend and implement sanctions against defaulting countries, citizens will begin to fill a sense of belonging thus bringing their best and contribute to the economic development of any nation irrespective of where they live!

There is no doubt that there exist United Nations, The G-8, The AU, European Union, Arab League, Shanghai Cooperation, Caribbean Community, among over 300 intergovernmental and 68,000 international organizations (both active and inactive). More separatists associations and organizations are also formed even within the unions thereby exacerbating the mistrust that continues to remain the bane of the entire world order! Lack of trust in each other, mutual suspicion, neglect, non- inclusion are the drumbeats that undermine convivial, genuine discussions for reconciliations, mutual co-operations, agreements, and memoranda endorsements among nations.

Consequences of these actions steer every country straight on its face. Economic instability, political upheavals, insecurity and youth restiveness across the globe, intolerance of bad leadership by citizens, rising challenges on our leaders as well as depleting natural resources and challenging high unemployment figures!

Irrespective of the manner in which countries continue to pretend to work together through bilateral agreements, as long as countries continue to barricade their borders without mutual respect for citizens of other countries in a more strategic manner, we would continue to preach mere lip-service gospel of regional integration, cooperation, alignment, and cross border relationships.

This paper therefore, examines the pitfalls of existing positions/ status of various countries of the world, particularly the dichotomy between the existing structure of nations with a view to recreate a model for strategic alliances in the restructuring of the global economy towards sustainable peace and development. This is the kernel of the treatise.

\section{Conceptual Review}

The term, "Alliance" has remained a very potent word for global associations, unions and collaborations aimed towards the achievement of common interests. Literally meaning to join forces in order to gain an advantage over something, somebody, an organization or an entity; an alliance is a relationship among people, groups, or states that have joined together for mutual benefit or to achieve some common purpose, whether or not explicit agreement has been worked out among them. Members of such alliance are therefore, referred to as 'allies'

Hence, there exist arrangements in which two or more countries, groups etc agree to work together to try to change or achieve something. Britain's military alliance with her North Atlantic Treaty Organization (NATO) partners; alliance between two companies to market a product; a close relationship, especially a marriage, between people are forms of alliances that exist, among others.

Forging of alliances have been reported in various literature. Japan made an alliance with Britain in 1902; political / military alliance with world powers during world war 1 and world war 11 among a list of 648 alliances between 1815 and 2003 based on the Alliance Treaty Obligations and Provisions( ATOP) (Leeds et al, 2002).

Most alliances have been quite small, with the average number of members being just over three. But the major powers and European states have been reckoned with alliances quite frequently. Just six European powers- the United Kingdom, France, Germany, Austria, Hungary, Italy, and Russia/ Soviet Union- account for one-quarter of all alliance memberships during that period. Many more alliances have existed between the period under review (1815-2003) and now. Whether political alliances, military alliances, or business alliances, what is important is that alliances are forged for mutual benefit or to achieve some common purpose.

On whether alliances have negative or positive effects, scholars have divided opinions on the impact of alliances. Some authors believe that allies fulfill their alliance commitments approximately $75 \%$ 
of the time, while democracies are seen to be more reliable allies than non-democracies. Other authors in 2018 study updated and extended the data from the Journal of Conflict Resolution study and found that allies only fulfill their commitments about $50 \%$ of the time from 1816 to 2003 . Also records show that "States honored their alliance commitments $66 \%$ of the time prior to 1945 but the compliance rate drops to $22 \%$ from 1945 to 2003 . The rates of fulfillment for defense pacts (41\%) and nonaggression pacts (37\%) are dramatically lower than offensive alliances (74\%)"( Berkemeier\& Fuhrmann, 2018).

On alliance preference, the international opinion according to 2017 polls holds that the United States was the most preferred ally internationally. Russia and China, who preferred one another, both trailed behind America globally. Four countries, Bulgaria, Greece, Slovenia, and Turkey, preferred Russia, despite being members of NATO.

In Pakistan, $72 \%$ of respondents preferred ties with China, the largest margin of any country surveyed, while $46 \%$ of Bangladesh preferred India. A total of 22 countries indicated a preference for the United Kingdom at a rate of $10 \%$ or more, but the United States was the only country to prefer the Britain over any other, at a rate of $43 \%$. Five countries preferred France at a rate of $10 \%$ or more, led by Belgium at a rate of $25 \%$.A single country, Iraq expressed no preference, while three other countries, Lebanon, Palestine , and Slovenia, expressed no preference at a rate of $11 \%$ or more, although at a smaller rate than their preference for Russia on the part of Lebanon and Slovenia, and China on the part of Palestine. Kosovo reported the most unified opinion, preferring the United States at a rate of $92 \%$, while Russia's most unified supporters were Mongolia (71\%), Armenia (67\%) and Serbia (56\%). In total, 21 countries expressed preference for America at a rate of $50 \%$ or more. Catalyst is a word used loosely in this treatise to mean something adopted to 'speed up' or catalyze a process. Hence, strategic alliance is used to speed up or catalyze the restructuring of the global economy.

Strategy is a modern phenomenon with a clear beginning in time. It is a term synonymous with the military. Strategy was first used by Count Guibert in 1779, but today, it has fallen into almost universal usage in social, political, economic, environmental, and military studies. The word " strategy" is from the Athenian title Strategos, for 'general' or "leader of troops" which was derived from the verb stratigema meaning ' to lead or command an army' and indeed, from ancient to contemporary times, the military assumed almost the monopoly of large scale planning for effective management. Not until the 1940s did large- scale planning characteristic of the military become evident in other areas of human endeavors at first, in imaginary conflicts or game theory, and thereafter, followed by business, industry and even government policy- making.

Today, as it were, every business engages in strategic planning. Thus, we can now speak correctly of strategic investment, strategic weapon, strategic theatre, strategic thought, marketing strategy, political strategy, and now, 'strategic alliance'!

Strategy depicts a plan of action designed to achieve a long term or overall aim or the art of planning and directing overall military operations and movements in a war or battle. It is also an action that managers take to attain one or more of the organization's goals. Hence the word, strategy is synonymous with terms like 'arrangement, blueprint, design, game, game plan, program, project, road map, scheme or system'. The above clarifications have become necessary to give a clear direction of the term 'strategy' and its use in the context of this paper and give credence to logical colorations of the variables of interest.

Therefore, whether strategy is considered from the standpoint of political, economic, environmental angles, or even wars, the focus of this paper is that much of these strategic energies should be channeled towards making the world a more unified place to live in! Whether strategic plans are of the types: gorilla, flanking, frontal; or even "operation desert-storm" and now "operation global storm", more emphasis should be placed on how these strategic formations can be employed to improve the economic base of nations vis- a-vis global economic transformations.

\section{Global Economic Restructuring}

The term 'restructuring' in this paper signifies an existing imbalance in the global economic arena. However, the type of restructuring here revolves around the diversification of economy of nations , investment in information and communication technology( ICT), technological transfer, cross- border 
trade exchange co -operations, intellectual property exchange relations, as well as political, social and psychological change.

When nations begin to recognize their individual capabilities and cooperate with each other, irrespective of whether it is underdeveloped, developing, or developed, in the new "global strategic alliance model", nations will in no distant time exit from poverty, disease, recession, insurgency, extremism unwarranted religious animosities and antagonisms. Hence, the dividing lines between the underdeveloped, developing and developed nations will become narrower and narrower for better global economy and world peace.

Dichotomy Between Underdeveloped, Developing and Developed Nations vis- a-vis Economic Underpinnings.

The nations of the world have since been polarized between underdeveloped, developing and developed countries. It is no gain saying that all fingers are not equal. It is also more fastidious to recognize that in a family setting, there is often the evidence of "first borns", "second borns" and "third borns", etc. While recognizing "big brothers" evidence in the polity of nations giving rise to acronyms such as underdeveloped, developing, developed, super powers, underdogs, among others, it is also pertinent to understand that irrespective of the status of nations, as far as these nations are part of the evolving " global village", " a unified family", so to speak, it therefore behoves member nations to offer helping hands in a strategic manner to build a virile, strong and united world that knows no poverty, disease, wobbling and fumbling economy, extremism, security challenges, as well as mutual suspicion and lack of trust.

As long as some countries continue to struggle about provisions of basic infrastructure, payment of salaries of public workers, maintenance of government apparatus and political structures,, dishonesty in executing government policies as well as ingrained corruption, there will continue to be the problem of economic recession, underfunding of projects, lack of basic amenities, poverty, disease etc leading to deprivations that characterize nations as underdeveloped and developing. But, when nations offer helping hand to each other and begin to assist each other to invest in manpower development and capacity building, entrepreneurship, infrastructure like standard hospitals to take care of health care of citizens, quality and functional educational systems, electricity, good land, sea and air transport networks as well as investment in ICT, latest technology and good governance, the mutual suspicions among nations will disappear and nations will begin to fast-track their development to catch up with the trend by utilizing their potentials and tapping into areas where each country has comparative advantage.

A country's culture for example, can lift a nation out of poverty. Great investments are currently being made in cultural tourism. Nigeria, for example, tapped into her culture about 30 years ago, and today, she earns over \#30 billion annually through cultural tourism. Nigeria's Nollywood, for example, is fast competing with Hollywood and other cultural artistry in the world. Other so - called less privileged countries of underdeveloped nomenclature can as well key into their rich potentials in a strategic manner! If nations can spend $50 \%$ of their expenses in political elections and campaigns, investments in security equipment's, wastages in political positions, execution of wars, insurgencies, etc, in capacity building, provision of strong infrastructural base and enabling environment for entrepreneurship development and youth employment, the world would remain more peaceful devoid of antagonism, religious extremism, insurgent attacks, separatist formations as well as ethnic cum racial colorations!

It is, therefore, on the above standpoint that the author makes bold to say that all forms of agitations for state creations/ independence, ethnic militia, kidnapping/ hostage takings, internet fraud, among others are indices for under development and/or lack of good governance!

Although, the general characteristics of underdevelopment consist of:

-Low per capita income (an underdeveloped country is a poor country)

-inequitable distribution of wealth (mostly exacerbated by corruption\}

-Deficiency of capital (as a result of overdependence on importation against increase in productivity)

-unemployment and underemployment (Due to low emphasis on entrepreneurship and creation of enabling environment)

-A dualistic economy (Due to overdependence on imports)

-Technical backwardness (Due to low investment in ICT and Latest Technology). 
The indices constitute major highlights in the underlying problems that characterize underdeveloped countries. Based on the Human Development Index (HDI), the list of ten most underdeveloped countries in Africa includes the following:

- Central Africa Republic: GDP Per Capita \$333

-The Gambia: GDP Per Capita \$371

- Niger: GDP Per Capita $\$ 415$

- Liberia: GDP Per Capita \$454

- Madagascar: GDP Per Capita \$463

- Democratic Republic of Congo: GDP Per Capita \$484

- Ethiopia: GDP Per Capita \$505

- Guinea: GDP Per Capita \$558

And the ten most underdeveloped countries in the world according to the Human development Index (HDI) are:

Niger (.354)

Central African Republic (. 367)

South Sudan (.388)

Chad (.404)

Burundi (.417)

Sierra Leone $(.419)$

Burkina Faso (.423)

Mali (. 427)

Notably, developed nations are generally categorized as countries that are more industrialized and have higher per capita income levels, while, developing nations are those that are less industrialized and have lower per capita income levels. The economic inequality between developed and developing nations basically revolves around the per capita income. To be considered a developed nation, a country generally has a per capita income around or above $\$ 12,000$. Most developed countries boost of per capita income of approximately $\$ 38,000$.

Based on the 2010 survey, the list of developed nations included United States, Canada, Japan, Republic of Korea, Australia, Taiwan, Israel, New Zealand, Scandinavia, Singapore, Taiwan, countries of Western Europe, and some Arab states. By 2012, the combined populations of these three countries accounted for around 1.3 billion people. The populations of developed countries are generally more stable, and it is estimated that they will grow at a steady rate of around $7 \%$ over the next 40 years!

In addition to having high per capita income and stable population growth rates, developed nations are also characterized by their use of resources. In developed countries, people consume large amounts of natural resources per person and are estimated to consume almost $88 \%$ of the world's resources.

Developing Countries, on the other hand, possess similar characteristics like the underdeveloped countries except that developing countries possess

-High population growth rate/ size

-Dependence on primary sector

-Dependence on exports of primary commodities

Developing nations include countries that are less industrialized and have lower per capita income levels. Developing nations can be further divided into moderately developed or less developed countries. Moderately developed countries have an approximate per capita income of between $\$ 1.000$ and $\$ 2,000$. The average per capita income for moderately developed countries is around $\$ 4,000$. Based on the 2012 survey, the list of moderately developed nations is exceptionally long and accounts for around 4.9 billion people. Some of the most recognizable countries that are considered moderately developed include Mexico, China, Indonesia, Jordan, Thailand, Fiji, and Ecuador. In addition to these specific countries, many others from Central America, South America, Northern and Southern Africa, southern Asia, Eastern Europe, the former U.S.S.R, and many Arab States, are all considered moderately developed countries.

Less developed countries are the second type of developing nations. They are characterized by having the lowest income, with a general per capita income of approximately less than $\$ 1,000$. In many of 
these countries also, the average per capita income is even lower (around \$500). The countries listed as less developed are found in Eastern, Western and Central Africa, India, and other countries in the Southern Asia. In 2012 survey also, there were around 0.8 billion people who lived in these countries and survived on extraordinarily little income.

From the foregoing, therefore, it can be said that there is a thin line between underdeveloped and developing countries. Hence, it can equally be deduced that there are two basic divisions of countries of the world. It is either a country is developed, or it is underdeveloped! Therefore, to bridge the gap between the two, the author believes in the formation of a strategic alliance between the underdeveloped and the developing countries and between the developing and the developed countries. These strategic alliances are therefore in the forms of global coalitions working together to make the world a better place. These coalitions / alliances can be formed in international exchange programmes bordering on economic, social, political, cultural, sustainable energy, international peace, and development.

Building strategic alliances/ coalitions does not in any way deny countries of their natural endowments and potentials; it does not stop the countries who are already rich from being rich- it will even propel them to get richer! It does not call for total neglect of nations' security apparatus. Countries must put measures to check unforeseen aggressions, attacks, strategic border control measures, economic and future development plans/ measures, strategic enabling laws to check and deal with crimes committed by citizens as well as non-citizens, among others.

The system of tagging opposing groups/ endangered nations with "names" is nice for purposes of identity, however, it is better to recognize the 'enemies' of the world peace in a more strategic manner by forging alliances, coalitions of trust and engaging the enemies in "continuous strategic dialogue" to knell the root causes of the issues at hand and seek appropriate measures to calm frayed nerves across the globe. Condemning or tagging nations with crimes is not the solution but dealing with criminality based on the established and existing extant laws of the united nations would be beneficial in creating a more convivial environment for all citizens, irrespective of colour or creed. The moment the barriers between separatists' groupings are broken through 'regular strategic dialogue', the moment a "new unified united nations" would emerge!

Considering the above standpoints, therefore, it is apparent to note that no country would lose anything if the remaining world population that is less developed joins the developed nations. Therefore, the time is ripe, the time for global coalition/ alliance for economic restructuring is now. As countries struggle out of the volatile situations brought about by civil unrest, corruption, tribal wars and deep poverty and engage in strong belief in its capabilities, strong commitment for success, determination to change the status quo, leveraging on areas of comparative advantage and excellent management of available resources, only then can genuine progress be noticed and the result of collaborations, strategic alliances for economic growth and development as well as desired global economic restructuring will be meaningful.

\section{Conclusions}

The world economy is evolving, and emerging trends indicate a tumultuous transition that requires global attention, rather than separatists' approach by individual nations or groups. Countries' potentials and present situations and levels can no longer be relied upon going by the demystification of economic forecasts by emerging trends of economic recession, burgeoning unemployment figures, changing patterns in taste, deforestation, depleting natural resources as well as political and security challenges.

This paper, therefore, is an attempt at developing a model for survival in the present global economic quagmire. The paper reviewed the dichotomies between the underdeveloped, developing and developed economies, believing that irrespective of the economic positions of countries, no one nation can boldly say, "I don't need your help" to the other countries. It is against this backdrop that the paper enjoins countries to think less of their ratings in the global economic arena and focus more on creating an enabling environment that will involve all citizens irrespective of creed, race or colour, in tackling global challenges together because an injury to one is injury to all!

Global economic restructuring, is a challenge to the entire world, hence a call is made for the adoption of strategic alliance between the developing and developed nations as a major step towards 
creating a more unified economic environment that offers every nation opportunity for growth and development as well as peaceful coexistence based on mutual trust and respect for each other.

\section{Recommendations}

The following recommendations have been put forward towards achieving the targets of global economic restructuring through the new model of strategic alliance:

i. Immediate convocation of international/global conferences on economic restructuring cutting across all nations, irrespective of the status in economic growth.

ii. A re- alignment and adjustments in the barriers posed by nations on inter regional employments.

iii. An increased tempo in cross- border relationships in entrepreneurship studies as well as other key educational and skill development programmes.

iv. Cross- fertilization of ideas, skills, competences and knowledge across nations irrespective of creed, colour or location.

v. A total re-skilling, re-tooling and reinvigoration of mutual coexistence rather than rugged individualistic and self- reliance approach of nations.

vi. An integration and leveraging on a new "'UK -Africa', 'Africa- America', 'Asia- America- Africa', coalitions for development.

vii. Formulation of new initiatives in International / Intercontinental/ Inter-regional free zones.

viii. A renewed vigour and strengthening of United Nations Industrial Development Organization (UNIDO), World Trade Organization (WTO), as well as United Nations International and Cultural Organization (UNICEF), UNDP, UNCTAD and other organizations to reflect current global changes and demands.

\section{References}

Alexander, T and Jane, S. (2019). Applying Systems Approaches to Diverse Contexts,

Journal of the Local economy Policy, 34(8),755-766.

Alex, T, Rhiannon, P, Jana, S. (2019). Beyond global Hub: broadening the Application of Systems Approaches, Journal of the Local Economy, 34(8).

Alvedalen, J and Boschma, R. (2017). A Critical Review of Entrepreneurial Ecosystems Research: Towards a Future Research Agenda, European planning studies 25(6), 887-903

Cooke, P (2002). Regional Innovation Systems: General Findings and some new evidence from biotechnology clusters. The Journal of Technology Transfer, 27(1), 133-145.

De Macido JB and Martins J.O. (2008). Growth, Reform Indicators and Policy Complementarities 1, The Economics of Transition, 16(2), 141-164.

De Macido, JB and Rocha, B. (2014). Are complementary reforms a "luxury" for developing countries? Journal of Comparative Economics, 42(2), 417-435

Eke, D.I, Onukwuli, A. G, Ochuba, C. D, Okafor, S.N. (2019) Building a new Africa without borders for economic diversification and sustainability: The Nigerian Perspective, Journal of Policy Review \& Development Strategies, $8(1)$.

Eke, O.A. (2000). Strategic Studies: Logical Focus in the 21st Century. Abakaliki, WillyRose and Appleseed Publishing Company,

Eke, O.A. (2009). Globalisation Challenges \& Nigerian Foreign Policy. Abakaliki, WilleyRose and Appleseed Publishing Company.

Euro-Asia Regional Report on the implementation of the Vienna Programme of Action, UNCHRLLS, ESCAP and UNECE (2019).

Fate, M. L, Mcarthur, J. W, Sachs, J. D, and Snow, T (2004). The Challenges Facing Landlocked Developing Countries, Journal of Human Development, 5(1).

Nordling, N and Pugh, R (2019). Beyond the "usual suspects"- Alternative Qualitative Methods for Innovation Policy Studies, African Journal of science and Development 5(2), 1-10.

Push, R. and Chiarini, T. (2018). A North- South Global Perspective, Journal of Innovation, and development 8(2), 227-248.

Scaramuzi, E. (2002). Incubators in developing Countries: Status and Development Perspectives into Development Program, Washington DC, The World Bank

Schmutzler, J, Suarez, M, Tsvetkova, A, et al (2017). Introduction to a context- specific two- way approach to the study of innovation systems in developing and transition countries, Journal of Policy \& development Strategies, 8(2).

Shinn, J (2020). Economic Inequality: Difference in Developed and Developing Nations (Online) Retrieved from http://economic goggle weblight.com (Accessed on 01/20/2020). 
Spiegel, B. (2016). Developing and governing entrepreneurial support programs in Edingurgh, Scotland, International Journal of Innovation and Regional Development. 7(2), 141-160.

UNCTAD: Landlocked Developing Countries: Facts and Figures. http://unctad.org/en/publicationslibrary/aldc2014 dl-en.pdf.

World Bank (2010). The Cost of Being Landlocked, Logistics Costs and Supply Chain Reliability, Directions in Development. http://openknowledge.worldbank.org/handle/10986/7420.

World Bank (2016a), China goes global with development banks. http://www.brettonwoodproject.org/2016/04/20508.

World Bank (2016b), Country Readings Diagnostic for Public- Private Partnerships. http://pppknowledgelab.org/d/3553/download.

World Bank. World Development Indicators. http://datacatalog.worldbank.org/dataset/worlddevelopmentindicators.

World Bank Energy Access Database- Tracking SDG7; The Energy Progress Report 2019. 